\section{Some Properties and Action of Poly(glutamic acid) Hydrolase II from Micromonospora melanosporea IFO 12515}

\author{
Tetsuo Muro, Yoichi Nagamori, * \\ Shigetaka OKADA* and Yoshio TominaGa \\ Osaka Municipal Technical Research Institute, \\ 6-50 Morinomiya 1-chome, Joto-ku. \\ Osaka 536, Japan \\ * Biochemical Research Laboratories, Ezaki Glico Co., \\ 6-5 Utajima 4-chome, Nishiyodogawa-ku, \\ Osaka 555, Japan \\ Received September 27, 1989
}

Since it was demonstrated that bitter peptides were produced from casein by the hydrolytic action of various proteases, ${ }^{1 \text { ' }}$ some workers have reported that hydrolysis of proteins with proteolytic enzymes is usually accompanied by the formation of bitter peptides which make foods unpalatable. ${ }^{2-5)}$ Studies ${ }^{6,7)}$ on the structure--taste relationship of bitter peptides demonstrated that some peptides consisting of hydrophobic amino acids have the bitterness generally and that the substrate specificity of proteases which have strong affinities to hydrophobic amino acids causes the formation of such bitter peptides. Therefore, to suppress the formation of the bitter peptides in the proteolytic digests of proteins, it is useful to obtain the proteases having strong affinities for hydrophilic amino acids.

In our preceding paper, ${ }^{8)}$ we reported that $\mathrm{Mi}$ cromonospora melanosporea IFO 12515 secreted two poly(glutamic acid) hydrolases (PGH-I and II) of which PGH-II was purified to an electrophoretically homogeneous state at a yield of $2.3 \%$ by ion exchange chromatography followed by isoelectric focusing and gel filtration. This study deals with the enzymatic properties and mode of action of PGH-II, using either poly-Glu or poly-Glu hydrolysate as a substrate.

In the enzyme assay, the reaction was done at $40^{\circ} \mathrm{C}$ and pH 9.0 with $0.5 \%$ poly-Glu (Peptide Institute, Inc., Osaka). After incubation for an appropriate time, the amounts of free amino groups formed were measured by the method of Yemm and Cocking. ${ }^{9)}$ One unit (U) of the activity was defined as the amount of enzyme liberating $1 \mu \mathrm{mol}$ of free amino groups per min.

The molecular weight of PGH-II was 32,000 by gel chromatography on Sephadex G-75, using bovine serum albumin, ovalbumin, chymotrypsinogen $A$, and ribonu- clease $A$ as standard proteins. The isoelectric point of PGH-II was 5.5, using carrier ampholites (pH 3-10, LKB Product AB, Sweden). The enzyme was most active at $\mathrm{pH}$ 10.0 and the optimum temperature of the enzyme was $50^{\circ} \mathrm{C}$. PGH-II was stable from $\mathrm{pH} 4.0$ to 10.0 at $40^{\circ} \mathrm{C}$ for $60 \mathrm{~min}$ of incubation and stable at temperatures below $50^{\circ} \mathrm{C}$ at $\mathrm{pH} 9.0$ for $15 \mathrm{~min}$.

In the study of the effects of inhibitors and metal ions, $0.5 \mathrm{ml}$ of the enzyme solution $(0.5 \mathrm{U} / \mathrm{ml})$ was incubated with $0.5 \mathrm{ml}$ of each inhibitor at $30^{\circ} \mathrm{C}$ for $15 \mathrm{~min}$, and with $0.5 \mathrm{ml}$ of each metal ion at $40^{\circ} \mathrm{C}$ for $60 \mathrm{~min}$ in $50 \mathrm{~mm}$ borate buffer ( $\mathrm{pH} 9.0$ ). As shown in Table I, PGH-II was inhibited by the chelators such as trisodium ethylenediamine tetraacetate (EDTA) and $o$-phenanthroline which are inhibitors of metal proteases. PCMB also inhibited the enzyme activity by about $50 \%$. However, the enzyme was not inhibited by DFP and PMSF which are typical inhibitors of serine proteases. Since PGH-II was not completely inhibited by high concentration of chelators, further study is needed to clarify the classification of this enzyme. When enzyme activity was assayed in the presence of $1 \mathrm{~mm}$ metal salts, most of them did not activate the enzyme. On the contrary, $\mathrm{Cu}^{2+}$ strongly inhibited the enzyme activity.

Table I. EFfects of Chemical Reagents on POLy(Glutamic aCid) Hydrolase II from Micromonospora melanosporea

\begin{tabular}{|c|c|c|}
\hline Reagent & $\begin{array}{l}\text { Concentration } \\
\text { (mM) }\end{array}$ & $\begin{array}{c}\text { Relative activity } \\
(\%)\end{array}$ \\
\hline None & & 100 \\
\hline $\mathrm{DFP}^{a}$ & 4 & 108 \\
\hline $\mathrm{PMSF}^{b}$ & 1 & 81 \\
\hline Chloroquine & 1 & 81 \\
\hline MIA & 1 & 83 \\
\hline PCMB & 1 & 47 \\
\hline \multirow[t]{2}{*}{ EDTA } & 10 & 21 \\
\hline & 25 & 9 \\
\hline \multirow[t]{2}{*}{$o$-Phenanthroline } & 1 & 19 \\
\hline & 5 & 3 \\
\hline N-Ethylmaleimide & 1 & 92 \\
\hline $\mathrm{CaCl}_{2}$ & 1 & 108 \\
\hline $\mathrm{CoCl}_{2}$ & $1 \quad 2$ & 80 \\
\hline $\mathrm{CuCl}_{2}$ & 1 & 3 \\
\hline $\mathrm{FeCl}_{3}$ & 1 & 110 \\
\hline $\mathrm{MgCl}_{2}$ & 1 & 95 \\
\hline $\mathrm{MnCl}_{2}$ & 1 & 87 \\
\hline $\mathrm{NiCl}_{2}$ & 1 & 52 \\
\hline $\mathrm{SrCl}_{2}$ & 1 & 109 \\
\hline
\end{tabular}

a iso-Propyl alcohol $(8 \%)$.

${ }^{b}$ Ethyl alcohol $(1 \%)$ was contained in the reaction mixture. DFP, diisopropylfluorophosphate; PMSF, phenylmethanesulfonyl fluoride; MIA, monoiodoacetic acid; PCMB, p-chloromercuribenzoate; EDTA, trisodium ethylenediamine tetraacetate. 
(A)

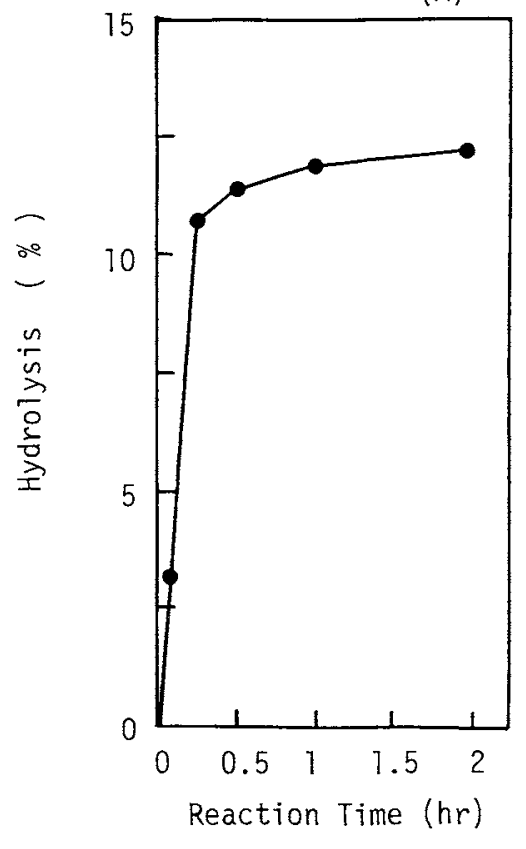

(C)

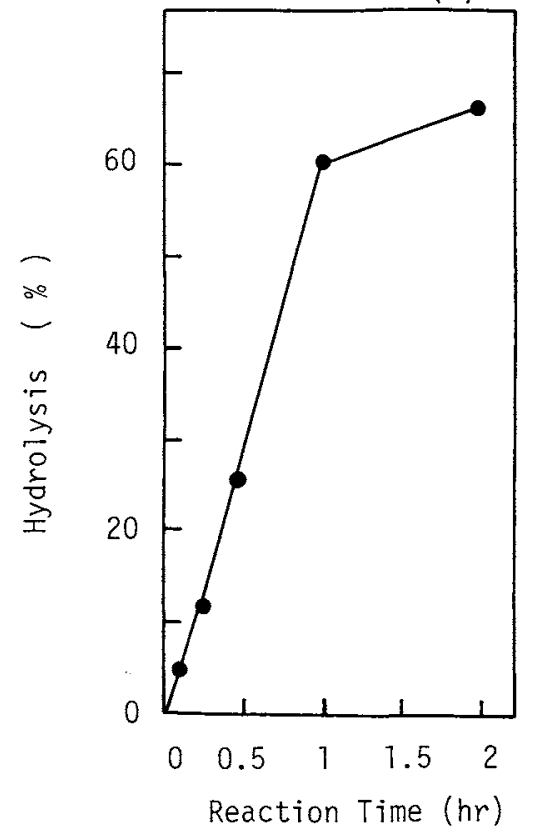

(B)

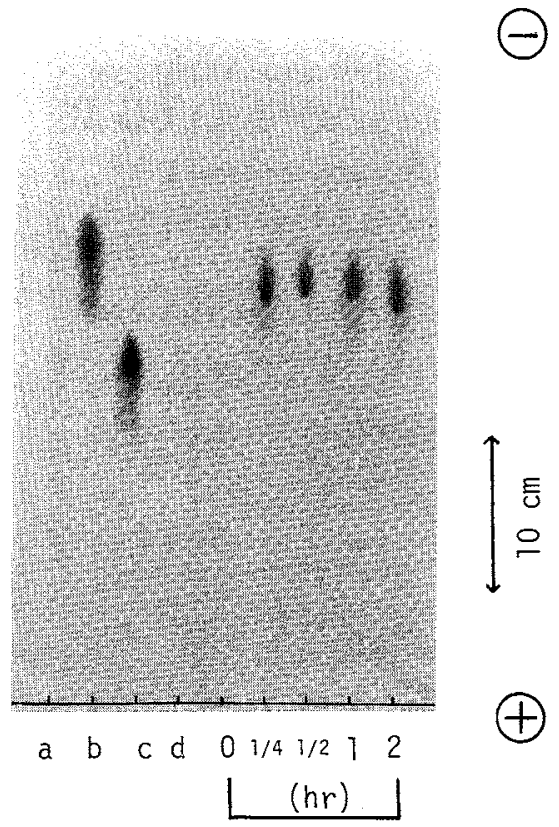

(D)

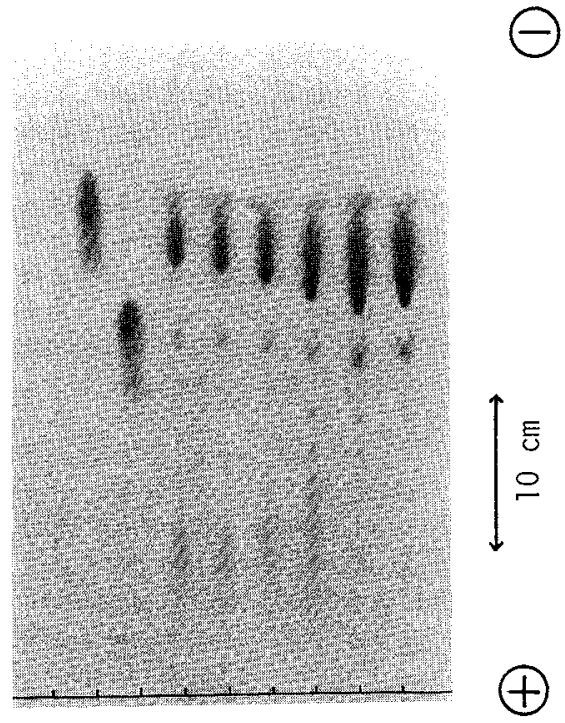

$\begin{array}{llllllllll}a & b & c & d & 0 & 1 / 4 & 1 / 2 & 1 & 2\end{array}$

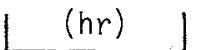

Fig. 1. Action of Poly(glutamic acid) Hydrolase II on Poly(glutamic acid) (or Poly(glutamic acid) Hydrolysate).

The degree of hydrolysis was calculated from the contents of free amino groups produced by hydrolysis of poly-Glu by $6 \mathrm{~N} \mathrm{HCl}$ at $110^{\circ} \mathrm{C}$ for $24 \mathrm{hr}$. Conditions of electrophoresis: formic acid-acetic acid-water (3:9:8), $\mathrm{pH} 0.8 ; 10^{\circ} \mathrm{C} ; 3,000 \mathrm{~V}$; electrophoresis, $2.5 \mathrm{hr}$.

(A), the course of hydrolysis of poly-Glu; (B), electrophoretic patterns of the hydrolysates: a, PGH-II; b, Glu; $c$, Glu-Glu; d, poly-Glu; (C), the course of hydrolysis of poly-Glu hydrolysate; (D), electrophoretic patterns of the hydrolysates: a, PGH-II; b, Glu; c, Glu-Glu; d, poly-Glu hydrolysate. 
To investigate the mode of action of PGH-II on polyGlu, the enzyme $(0.5 \mathrm{U})$ was reacted with $0.5 \%$ poly-Glu in $25 \mathrm{~mm}$ borate buffer ( $\mathrm{pH} 9.0$ ) at $40^{\circ} \mathrm{C}$. After an appropriate time of incubation, $0.1 \mathrm{ml}$ of the reaction mixture was measured colorimetrically with ninhydrin reagent. As shown in Fig. 1(A), this enzyme strongly hydrolyzed poly-Glu in the initial stage of the reaction and then hydrolyzed it gradually. Furthermore, the reaction products were analyzed by high voltage paper electrophoresis (HVPE), using Toyo No. 50 filter paper $(60 \times 30 \mathrm{~cm})$. After the HVPE, reaction products were stained with nihydrin reagent. Figure 1(B) shows that only glutamic acid (Glu) was produced from poly-Glu by PGH-II in all stages of the enzyme reaction. However, the production of oligomers of Glu which may be intermediates of the reaction was not observed in this case.

To investigate the mode of action of PGH-II, we studied its action on poly-Glu hydrolysate having lower degrees of polymerization than that of poly-Glu. The poly-Glu hydrolysate was prepared from poly-Glu as follows. The poly-Glu was hydrolyzed with $6 \mathrm{~N} \mathrm{HCl}$ at $110^{\circ} \mathrm{C}$ for $4 \mathrm{hr}$ and then evaporated until the $\mathrm{HCl}$ was completely removed. The degree of hydrolysis of this preparation was about $30 \%$. The enzyme $(0.5 \mathrm{U})$ was added to $0.5 \%$ polyGlu hydrolysate in $25 \mathrm{~mm}$ borate buffer ( $\mathrm{pH} 9.0$ ). After an appropriate time of incubation at $40^{\circ} \mathrm{C}$, the reaction mixtures were assayed by the same methods described above. As shown in Fig. 1(C), this enzyme reaction sufficiently proceeded far more with poly-Glu hydrolysate as a substrate, compared with poly-Glu (Fig. 1(A)). From these results, it can be considered that poly-Glu hydrolysate is a good substrate for PGH-II, compared with poly-Glu having high molecular weight (above 8,000). In addition, spots of oligomers of Glu were observed below the spot of Glu-Glu after 30 and $60 \mathrm{~min}$ of incubation by HVPE (Fig. 1(D)). The oligomers of Glu were hydrolyzed for $120 \mathrm{~min}$ and then Glu and Glu-Glu were produced.

Though some studies have reported proteolytic enzymes that catalyze the hydrolysis of peptide bonds on the carboxyl-terminal side or amino-terminal side of Glu, there are rarely found reports relating to the action of enzymes on poly-Glu. Thereofre, it can be considered that this study is the only report which describes the action of an enzyme on poly-Glu and poly-Glu hydrolysate. At present we are investigating the mechanism of hydrolysis of poly-Glu by PGH-II.

\section{References}

1) T. K. Murray and B. E. Baker, J. Sci. Food Agric., 3, 470 (1952).

2) M. Yamashita, S. Arai and M. Fujimaki, Agric. Biol. Chem., 33, 321 (1969).

3) T. Matoba, R. Hayashi and T. Hata, Agric. Biol. Chem., 34, 1235 (1970).

4) N. Minamiura, Y. Matsumura, J. Fukumoto and T. Yamamoto, Agric. Biol. Chem., 36, 588 (1972).

5) N. Minamiura, Y. Matsumura and T. Yamamoto, $J$. Biochem., 72, 841 (1972).

6) J. Kirimura, A. Shimizu, A. Kimizuka, T. Ninomiya and N. Katsuya, J. Agric. Food Chem., 17, 689 (1969).

7) K. Otagiri, Y. Nosho, I. Shinoda, H. Fukui and H. Okai, Agric. Biol. Chem., 49, 1019 (1985).

8) T. Muro, Y. Nagamori, S. Okada and Y. Tominaga, Kagaku to Kogyo (Osaka), 63, 368 (1989).

9) E. M. Yemm and E. C. Cocking, Analyst, 80, 209 (1955). 